\title{
A MILITÂNCIA DE PASCHOAL LEMME EM DEFESA DA CONSTRUÇÃO DE UM SISTEMA NACIONAL DE ENSINO
}

\section{Resenha do livro:}

KASTELIC, Eloá Soares Dutra. O percurso de Paschoal Lemme: defesa da escola pública, gratuita e estatal. Campinas, SP: Autores Associados, 2014. (Coleção Memórias da Educação)

\section{Resenha por:}

Gizeli Fermino Coelho'

Taís Renata Maziero Giraldelli ${ }^{2}$

Maria Cristina Gomes Machado $^{3}$

Eloá Soares Dutra Kastelic graduou-se em Pedagogia pelo Centro Universitário Filadélfia (UNIFIL), obteve o título de mestre pela Universidade Estadual de Maringá (UEM), título de doutora em Letras e Linguística pela Universidade Federal da Bahia (UFBA) e atualmente é docente da Universidade Estadual do Oeste do Paraná (UNIOESTE). A obra intitulada "O Percurso de Paschoal Lemme: defesa da escola pública, gratuita e estatal", a qual nos propomos a resenhar, é fruto de seu trabalho desenvolvido por esta Universidade.

A autora escolheu o intelectual e educador Paschoal Lemme, para fazer uma análise histórica sobre suas ideias educacionais expressas entre as décadas de 1930 e 1960 em defesa da escola pública e gratuita.

Composta por três capítulos a obra possui uma linguagem fluída e os capítulos se entrelaçam, o que estimula sua leitura e à torna prazerosa. O Livro foi prefaciado pela Professora Doutora Maria Cristina Gomes Machado docente e pesquisadora do Departamento de Fundamentos da Educação da Universidade Estadual de Maringá-PR. A edição do livro foi impressa pela Editora Autores Associados no ano de 2014.

Logo na introdução, Kastelic enfatiza os motivos que a levaram a escolher as ações de Lemme como objeto de investigação e reflexão. Para a autora o intelectual foi um homem que envolveu-se com questões de seu tempo, tais como: a necessidade da construção de um sistema nacional de ensino, capaz de atender ao novo modelo de vida que impulsionava as relações de produção dos homens.

As primeiras décadas do século XX, período em que Lemme atuou como educador e expressou suas ideias, foi marcado por renovações e reconstruções presentes não só no Brasil, mas em todo o mundo. Época da internacionalização das relações sociais de produção que deu forma a sociedade capitalista, caracterizado por acontecimentos 
gigantescos como a Primeira (1914-1918) e a segunda Guerra Mundial (1939-1945). Além disso, o educador viveu em um período de repressão política impulsionado pelo governo ditatorial de Getúlio Vargas que tinha como preocupação central, conter os movimentos de massa que acentuou-se no país nos períodos pós Guerra, momento em que a escola pública passou a ser vista como uma instituição capaz de salvar os brasileiros fragilizados economicamente pelos confrontos (KASTELIC, 2014, p. 2).

Lemme diferentemente de seus pares entendia que a educação era apenas um elemento para que o país continuasse a cursar o caminho da transformação social tão almejada, e não o motor principal da modernização. Para o intelectual, a mola mestra para a modernização do país estava vinculada ao fomento do desenvolvimento econômico e uma melhor distribuição de renda.

No primeiro capítulo, cujo titulo é "O percurso de Paschoal Lemme: a formação de um educador de esquerda", Kastelic apresenta o percurso da formação profissional e intelectual do autor, o qual teve a infância e adolescência bastante simples, mas continuamente cercado por livros, gosto que tornou-se mais apurado no magistério e o acompanhou até sua maturidade. (KASTELIC, 2014, p. 11).

$\mathrm{O}$ educador teve uma vida longa, o que possibilitou a vivenciar significativas transformações socioculturais que influenciaram seu pensamento e suas obras. Portanto, seu posicionamento diante da concepção de educação e democracia fundamentou-se em fatos e em repercussões na sociedade brasileira, questões que o levaram a compreender múltiplas determinações de uma mesma questão.

No período em que atuou como educador e servidor público, Paschoal Lemme entrou em contato com obras de pensadores chamados materialistas, marxistas e esquerdistas, o que o levou a optar pelas teses fundamentais da filosofia marxista. Esta filosofia o levou a pensar a educação, a sociedade e inclusive a economia de forma coletiva. Além disso, questões como igualdade de oportunidades e democratização social, foram sempre evidenciadas como uma preocupação em suas obras.

O segundo capítulo cujo título "A militância do educador Paschoal Lemme em defesa da escola pública", nos é apresentado a posição de Lemme diante da educação e seu ensino assim como o próprio procurou discutir o principais problemas que a assolavam. Durante a trajetória do educador que se preocupou com várias questões como a formação dos professores, a educação dos adultos, com o ensino primário, o ensino secundário e o ensino superior.

Durante o terceiro capítulo, titulado "Um pioneiro e o debate entre o público e privado: Paschoal Lemme e Carlos Lacerda na LDB de 1961". No capítulo é evidenciando a fundo a trajetória de Paschoal Lemme em destaque na elaboração da LDB/1961, sempre em defesa da educação pública e na tentativa de combater o substitutivo Carlos Lacerda que defendia a iniciativa privada no setor educacional.

Discutida desde 1948 a LDB era inspirada em princípios liberais da democratização, entretanto, apenas em 1956 com a reorganização política e definições econômicas do país, após dois anos, o debate da escola pública e privada volta a ser discutido, iniciando-se novamente a discussão do projeto da LDB, de acordo com Kasteli, Lemme nesse momento teria um importante papel, ao ser convidado a escrever sobre a defesa a escola pública. 
O intenso debate durou anos, assim como a LDB tramitou por treze anos, e para o educador Lemme qualquer que fosse o desfecho, a Lei deveria atender os interesses do povo e das gerações, e se preciso o debate haveria de continuar. Paschoal Lemme aposentou-se em 1961 devido a Ditadura Militar e retomando suas publicações em 1978, se tornou reconhecimento no meio acadêmico, recebeu homenagens, até o fím de sua vida.

Kastelic trouxe em seu trabalho a intenção de mostrar o lado militante de Paschoal Lemme na educação e defesa da escola pública. Além da importância do assunto, que ainda é muito discutido na atualidade, o ensino público versus o ensino privado, por meio de um debate histórico de grande relevância para a história da educação brasileira e destacando figuras renomadas, com suas contribuições para a educação e para a primeira Lei de Diretrizes e Bases da educação brasileira. De leitura prescindível, o livro é uma fonte inesgotável para o estudo do assunto, em torno de discussões e debates da educação pública e democrática. 